\title{
GEOGRAPHIC VARIATION AMONG HERBIVORE POPULATIONS IN TOLERANCE FOR A CHEMICALLY RICH SEAWEED
}

\author{
ERIK E. SotKA ${ }^{1,3}$ AND MARK E. HAY ${ }^{2}$ \\ ${ }^{1}$ Institute of Marine Sciences and Department of Biology, University of North Carolina at Chapel Hill, \\ 3431 Arendell Street, Morehead City, North Carolina 28557 USA \\ ${ }^{2}$ School of Biology, Georgia Institute of Technology, Atlanta, Georgia 30332-0230 USA
}

\begin{abstract}
Previous investigations have shown that the sedentary amphipod Ampithoe longimana escapes consumers by selectively living on and eating chemically defended seaweeds in the genus Dictyota. However, A. longimana and Dictyota overlap only in the southern portion of the amphipod's range; Dictyota is not available to amphipods from more northerly regions. We used this disjunction in distribution to test the hypothesis that A. longimana populations co-occurring with Dictyota would have greater tolerance for the seaweed's chemical defenses and would display higher feeding preference for, and fitness on, the seaweed than would more northerly populations. We also evaluated the genetic vs. phenotypic basis of these patterns and attempted to detect trade-offs between tolerance for Dictyota and ability to use other plants as foods. Such geographic studies of herbivory have been conducted using terrestrial insects, but few studies have focused on other herbivores, and this is especially true for marine systems. In multiple-choice feeding assays with both field-collected and laboratory-reared adults, a North Carolina population of $A$. longimana sympatric with Dictyota more readily fed on Dictyota and was more resistant to Dictyota's deterrent chemistry than was a Connecticut population from outside of Dictyota's geographic range. When raised on Dictyota menstrualis and D. ciliolata, A. longimana juveniles from North Carolina grew faster, matured faster, and produced more reproductive females than did Connecticut juveniles. The differential tolerance for Dictyota has a genetic basis, as it was maintained through two generations grown to maturity in a common environment. When several northern and southern populations were assayed, they displayed similar regional differences in feeding preferences.

Though southern juveniles had higher fitness on Dictyota than northern juveniles, southern juveniles performed as well as northern juveniles when raised on seven other seaweeds, including seaweeds (e.g., Fucus vesiculosus and Sargassum filipendula) that produce secondary metabolites in a different class from those found in Dictyota. Thus, tolerating Dictyota did not incur detectable performance trade-offs when juveniles were confined to feeding on alternative seaweeds. Our results suggest that the evolution of host preferences may depend more on the host value as a refuge from enemies than on minimizing the costs of tolerating plant secondary metabolites.
\end{abstract}

Key words: amphipod; Ampithoe; Dictyota; feeding preference; geographic variation; performance trade-offs; plant-herbivore interaction; seaweed chemical defense; specialization.

\section{INTRODUCTION}

Many plants produce chemicals as defenses against herbivores, and some herbivores respond by evolving increased tolerance to these chemical defenses (Rosenthal and Berenbaum 1992). Because herbivores play important roles in structuring plant communities (Lubchenco and Gaines 1981, Crawley 1997, Hay 1997) and because overcoming plant defenses was likely a key innovation in herbivore evolution and diversification (Berenbaum et al. 1996), understanding herbivore interactions with plant secondary metabolites has

Manuscript received 29 May 2001; revised 15 January 2002; accepted 7 February 2002.

${ }^{3}$ Present address: Department of Organismic and Evolutionary Biology, Harvard University, 16 Divinity Avenue, Cambridge, Massachusetts 02138 USA.

E-mail: esotka@oeb.harvard.edu implications for coevolution, specialization, speciation, and the dynamics of populations and communities (Strong et al. 1984, Hay and Fenical 1988, Fritz and Simms 1992, Bernays and Chapman 1994).

Terrestrial ecologists studying insect tolerance to plant defenses often investigate how tolerance changes over the geographic range of the insect, in part because it is common for an insect's range to extend beyond that of its preferred host plant (Strong et al. 1984). Allopatric populations of these insect herbivores are thus confronted with locally distinct floral communities, and often show highest affinity for, or fitness on, local plants (e.g., Rausher 1982, Scriber 1986, Berenbaum and Zangerl 1998; but see Thompson 1993). If these differences are genetically based, this evidence supports the hypothesis that plants are a strong selective agent in the genetic differentiation of herbivorous insects, and at times, in their speciation (Mitter et al. 
1988, Bush 1994). This literature is dominated by studies on insects that are locally monophagous (Fox and Morrow 1981), yet evidence is growing that plants can also drive differentiation of locally polyphagous populations (e.g., Sword and Dopman 1999).

There are few marine investigations of intraspecific variation in herbivore tolerance for seaweeds. Rather, marine studies on herbivore tolerance have focused on comparisons among species (e.g., Hay et al. 1987, Schupp and Paul 1994, Steinberg et al. 1995) . Genetic variation within a single species of herbivore offers a complementary tool for understanding plant-herbivore interactions, but has rarely been used by marine ecologists. For example, there is evidence that species of herbivores in biogeographic regions dominated by chemically rich seaweeds are more tolerant of those metabolites than are species of herbivores from regions without such seaweeds (e.g., Steinberg et al. 1995, Cronin et al. 1997). An analogous test of this hypothesis could directly compare populations of a single species of marine herbivore that occur in two or more biogeographic regions, one of which does not contain the plants of interest (e.g., Stachowicz and Hay 2000).

We explored geographic variation in herbivore tolerance of seaweed defenses in the amphipod Ampithoe longimana (Smith 1873), a small herbivorous crustacean (adults $<1 \mathrm{~cm}$ length) found on a diverse array of large seaweeds in shallow waters of the northwest Atlantic Ocean (Nelson 1980a; E. E. Sotka, personal observation). This amphipod broods its offspring, builds tubes on host plants in which it lives with mates and offspring, and reaches sexual maturity at an age of $\sim 20 \mathrm{~d}$ when occupying high quality seaweeds (CruzRivera and Hay 2001). As such, these amphipods are similar to terrestrial insects (e.g., butterflies) whose females choose relatively large plants on which the herbivorous juveniles develop.

In North Carolina, A. longimana prefers and performs well on brown seaweeds of the genus Dictyota (Duffy and Hay 1991, 2000, Cruz-Rivera and Hay 2001). This amphipod is unusual in this respect, as most herbivores in North Carolina are deterred from feeding by the diterpene alcohols produced by the plants (Hay et al. 1987, Duffy and Hay 1991, Cronin and Hay $1996 a, b)$. Because omnivorous fishes avoid foraging on Dictyota, mesograzers lower their predation risk by associating with the plant. During seasons when fishes are abundant, small herbivores that cannot utilize Dictyota decline or become locally extinct, while A. longimana densities may increase due to the association with Dictyota (Duffy and Hay 1991, 1994). These associational refuges also occur among other small marine animals with limited host ranges (e.g., Hay 1992, Sotka et al. 1999, Stachowicz and Hay 1999).

Along the eastern shore of the United States, the northern-most range of the amphipod A. longimana exceeds that of Dictyota species. Dictyota does not regularly occur northward of the North Carolina/Virginia border (Richardson 1979). However, populations of the amphipod are known from the Florida Bay to at least the Gulf of Maine (Bousfield 1973; E. E. Sotka, personal observation). Thus, amphipods between Virginia and Maine will not encounter Dictyota. These distribution patterns provide the opportunity to test the hypothesis that populations that co-occur with Dictyota have higher feeding preference for the plant and greater tolerance for its secondary metabolites than do populations outside of the plants' geographic range, and that this adult preference translates into differences in juvenile fitness.

\section{Methods}

\section{Sites and organisms}

Populations of the amphipod A. longimana were initially collected from two sites: Millstone, Connecticut $\left(41^{\circ} 16^{\prime} \mathrm{N}, 72^{\circ} 09^{\prime} \mathrm{W}\right)$ and Morehead City, North Carolina $\left(34^{\circ} 42^{\prime} \mathrm{N}, 76^{\circ} 46^{\prime} \mathrm{W}\right)$. Both shallow subtidal sites $(<3 \mathrm{~m}$ depth) were dominated by seagrass beds and epiphytic and drift macroalgae and were highly saline (Connecticut $=26-30 \%$ [parts of dissolved salts per thousand parts of water]; North Carolina $=31-34 \%$ ) due to their close proximity to Atlantic Ocean inlets. The average monthly temperatures at the Connecticut site are cooler than those of North Carolina, especially in the summer months (Connecticut ranges from $3^{\circ}$ to $20.5^{\circ} \mathrm{C}$; North Carolina ranges from $6^{\circ}$ to $28^{\circ} \mathrm{C}$ ) (Sutherland and Carlson 1981; J. Terwin, personal communication).

Amphipods were collected from a variety of seaweeds that occur in Connecticut and North Carolina, primarily the brown seaweed Ectocarpus spp. and green ephemeral seaweeds (e.g., Enteromorpha spp. and Bryopsis spp.). To minimize potential effects due to North Carolina amphipods having recent experience with Dictyota, amphipods in North Carolina were never collected from Dictyota species or during times of the year when species of Dictyota were most abundant (i.e., warm summer months). Generally, seaweeds were placed in buckets in the field, returned immediately to the laboratory, and sorted by hand for amphipods. Connecticut amphipods were collected at water temperatures of $12-15^{\circ} \mathrm{C}$, sorted at the University of Connecticut's Marine Laboratory (Avery Point, Connecticut, USA), placed into plastic containers and transported in coolers to the Institute of Marine Sciences (IMS) in Morehead City, North Carolina, USA. North Carolina populations were collected at water temperatures of $17-20^{\circ} \mathrm{C}$ and immediately returned to the laboratory. Both populations were raised very slowly $\left(\sim 0.5^{\circ} \mathrm{C}\right.$ per day) to room temperature $\left(\sim 20^{\circ} \mathrm{C}\right)$ for subsequent rearing and feeding assays. We are certain that both these populations are A. longimana, as they are morphologically similar and produce fertile hybrid offspring. Further, nuclear and mtDNA sequence data indicate population-level rather than species-level di- 
vergence (E. E. Sotka, J. P. Wares, and M. E. Hay, unpublished manuscript).

In May 1998, field-collected adults were used for feeding behavior assays, their offspring were used for fitness assays, and then all were sacrificed. In May 1999 and 2000, the offspring of field-collected adults were raised in laboratory cultures on an array of seaweeds (but not Dictyota). The feeding behavior of adults from this second generation was assessed as well as the feeding behavior and fitness of their offspring (third generation). The cultures were kept at room temperature and a salinity of $\sim 30 \%$ o. Both Connecticut and North Carolina populations would experience these physical conditions in the field during the course of a year. Seawater in plastic tubs $(\sim 5 \mathrm{~L})$ was aerated constantly and changed every $2-4 \mathrm{~d}$ by pouring through a Nitex screen (mesh size $=500 \mu \mathrm{m}$; Tetko, Incorporated, Depew, New York, USA) to prevent passage of cultured amphipods. Water was replaced with filtered seawater collected from Bogue Sound, North Carolina. There were two tubs per population, and food was added when needed. All seaweeds added to the cultures (Enteromorpha, Ectocarpus, Sargassum, Gracilaria, and Hypnea) were first bathed in fresh water for at least two 30-s intervals; this eliminates the introduction of local A. longimana, which are very susceptible to fresh water stress and immediately leave plants placed in fresh water (Holmlund et al. 1990).

The seaweed genera used for feeding behavior and fitness assays occur in both North Carolina and Connecticut, with the exception of Dictyota species ( $D$. menstrualis and D. ciliolata), which are found in North Carolina, but not Connecticut. Seaweeds were collected in Bogue Sound, North Carolina, within a $12 \mathrm{~km}$ radius; the brown seaweeds Sargassum filipendula, D. menstrualis, and D. ciliolata, the red seaweeds Gracilaria tikvahiae and Hypnea musciformis, and the green seaweed Codium fragile were collected from a subtidal boulder jetty (Radio Island Jetty), the brown seaweed Fucus vesiculosus was collected at an intertidal boulder field, and the green seaweeds Enteromorpha sp. and Ulva sp. were collected from floating docks. Each of these seaweeds, with the exception of $D$. ciliolata, can be found at the seagrass site from which North Carolina populations of A. longimana were collected, but the density of seaweeds at the seagrass site is neither large nor persistent enough to harvest in sufficient quantities for these experiments.

\section{Feeding assays}

To determine feeding preferences, amphipods from each geographic region were given an array of seaweeds and allowed to feed for several days. Groups of adult amphipods (4-8 amphipods per replicate) were simultaneously offered a choice between pre-weighed pieces of tissues from eight seaweeds. Pieces were removed from each plant, blotted dry, weighed ( $\pm 1 \mathrm{mg}$ ), and placed in plastic bowls filled with $\sim 1 \mathrm{~L}$ of seawater.
To minimize bias in feeding preference due to encounter rates, tissues from each seaweed were added to the choice assay bowls at a blotted wet mass equivalent to $3 \mathrm{~cm}^{2}$ ( $\pm 10 \%$ ), according to a surface area to mass ratio calculated for each seaweed. Projected surface areas were determined using a LI-COR 3000 surface area meter (LI-COR, Lincoln, Nebraska, USA). For each bowl with amphipods, an identical bowl with pieces from the same plants was run without amphipods; this acted as a control for autogenic changes in plant mass unrelated to amphipod feeding. Replicates were stopped after the amphipods had eaten at least half of one plant piece, or when up to $96 \mathrm{~h}$ had elapsed. Plant pieces were blotted and reweighed, and the change in wet mass of each piece was scaled to account for autogenic changes in plant mass using the formula $T_{\mathrm{i}}\left(\mathrm{C}_{\mathrm{f}} / \mathrm{C}_{\mathrm{i}}\right)-T_{\mathrm{f}}$, where $T_{\mathrm{i}}$ and $T_{\mathrm{f}}$ represent the tissue subject to grazing and $C_{\mathrm{i}}$ and $C_{\mathrm{f}}$ represent the control tissue, before (i) and after (f) the experimental run. Replicate North Carolina (NC) and Connecticut (CT) bowls were placed side by side ( $n=17$ in 1998, $n=$ 20 in 1999), received tissue from the same individual seaweed, and had their own autogenic control. Two of 20 NC replicates were dropped from analysis in 1999 because nearly all amphipods in these replicates died during the assay. To evaluate feeding preferences of amphipods from a single site, the data were standardized to the number of individuals in a replicate and amount of time the assay ran. We used a nonparametric Friedman's test for the whole data set and also to evaluate pairwise post hoc differences among seaweeds (Roa 1992, Zar 1996). To directly assess whether the North Carolina and Connecticut adults differed in their relative preferences, we performed nonparametric Mann-Whitney tests on the proportion of each target seaweed consumed relative to the total amount consumed within each bowl. Proportions were used rather than absolute values because of differences among replicates in total consumption rates. We used a sequential Bonferroni adjustment in the $P$ value to account for the number of comparisons (Rice 1989).

To assess how readily the adults from each population would accept individual seaweeds as foods when no other choices were available, adults were isolated with tissue from only one of the eight seaweeds used in the multiple choice assay. For this no-choice assay, pieces of seaweed ( $\sim 100-400 \mathrm{mg})$ were removed from each plant, blotted dry, weighed $( \pm 1 \mathrm{mg})$, and added to separate dishes containing $\sim 250 \mathrm{~mL}$ of seawater. Each replicate consisted of two bowls, each containing four to five field-collected adults (1998) from one of the two populations, and a third bowl without amphipods in order to assess autogenic changes in seaweed mass. Plants were reweighed after $60 \mathrm{~h}$, and changes in mass were scaled using the autogenic mass change formula shown above. Before assessing whether these populations were responding to seaweeds differently, the data were standardized to the number of individuals 
in a replicate and amount of time the assay ran. We performed a two-way ANOVA using site and seaweed species as independent factors. Before analysis, we logtransformed the data; this satisfied assumptions of normality (Shapiro-Wilk $W$ test, $P>0.05$ ) and homoscedasticity (Bartlett's test, $P>0.05$; Zar 1996). To assess whether the populations were feeding in response to quantity of available organic material, mean adult feeding rates for each population on each seaweed were regressed onto ash-free dry mass (i.e., AFDM) for that species. The AFDM was calculated from the average of four samples of $6-11 \mathrm{~mL}$ frozen tissue ( $<7 \mathrm{mo}$ old $)$, dried for $4 \mathrm{~d}$ at $\sim 60^{\circ} \mathrm{C}$, weighed, ashed for $6 \mathrm{~h}$ at $\sim 450^{\circ} \mathrm{C}$, and then weighed again. Codium was removed from these analyses because much of its tissue severely degraded (even in control containers) during the nochoice assay.

To assess whether juvenile feeding behavior differed between the populations, third generation juveniles (i.e., offspring from the second generation cultured in the common environment described above) were allowed to feed on pre-weighed tissue from Enteromorpha or D. menstrualis. Only those juveniles smaller than the size at which $10 \%$ of females became mature were utilized (i.e., first three segments are smaller than $550 \mu \mathrm{m}$; average size of females at maturity is 670 $\mu \mathrm{m})$; it is likely these animals were all $<2$ wk old. It is very difficult to determine sexual maturity in males of this amphipod species, so all juveniles, male and female, were subject to this same standard. The juveniles were starved for $\sim 6 \mathrm{~h}$ before the assay and 10 juveniles were placed in each bowl. Replicate North Carolina and Connecticut bowls were placed side by side, received tissue from the same individual seaweed, and had their own autogenic control. Feeding was allowed for $96 \mathrm{~h}$, and the plants were reweighed. One Enteromorpha replicate was removed because the autogenic control plant degraded during the course of the assay. Feeding rates were scaled to account for autogenic changes in plant mass (see above), and then divided by the average initial size of juveniles and the number of surviving juveniles within each replicate. Although North Carolina juveniles suffered higher mortality than Connecticut juveniles, this pattern occurred for both Enteromorpha (mortality of juveniles from NC [46\%] and CT [18\%]) and D. menstrualis (mortality of juveniles from NC [37\%] and CT [7\%]), indicating that detectable site differences in the consumption of seaweeds (see Results) were not due to differential mortality but differential feeding behavior. This method assumes that the deceased juveniles did not consume a considerable mass of food; however, we do not believe this assumption compromises our results because most amphipods that died during the course of the assay died early and/or did not readily feed before dying (E. E. Sotka, personal observation). To test for an interaction between site and seaweed, the scaled feeding rate for amphipods from North Carolina was subtracted from that for Connecticut within each replicate and compared between the two seaweeds using a nonparametric Mann-Whitney test.

\section{Bioassay guided fractionation of Dictyota extracts}

To assess whether population differences in feeding preference for $D$. menstrualis were mediated by the chemical constituents of the plant, we extracted and further partitioned the lipid-soluble extract of $D$. menstrualis and assayed the feeding tolerance of laboratory-reared Connecticut and North Carolina amphipods toward these extracts. The extraction and chromatographic methods were adapted from Cronin et al. (1995) and Stachowicz and Hay (1999). On 12 July 2000, 20 individual D. menstrualis plants were collected from a subtidal boulder jetty and brought immediately to the Institute of Marine Sciences. Two 200$\mathrm{mg}$ pieces were broken off of each plant and each piece was then shredded into tiny pieces and placed in one of two scintillation vials containing $5 \mathrm{~mL}$ of $2: 1 \mathrm{di}-$ chloromethane (DCM):methanol (MeOH). One of these vials was immediately placed in a $-20^{\circ} \mathrm{C}$ freezer for chromatographic separation at a later date (see below). The tissue in the second vial was extracted three times using a total of $15 \mathrm{~mL}$ of 2:1 DCM:MeOH. The extract was filtered through glass wool and the solvent was evaporated using a stream of $\mathrm{N}_{2}$. Half of the extract from this 200-mg tissue was used for the bioassays, while the other half was used to quantify the concentration of the diterpenes dictyol $\mathrm{E}$ and pachydictyol A via high-pressure liquid chromatography (HPLC).

For the bioassays, the extract or partition from 100 mg wet mass of $D$. menstrualis was dissolved in 300 $\mu \mathrm{L}$ ethyl ether and coated onto two 50-mg (blotted wet mass) pieces of fresh Ulva using a $500-\mu \mathrm{L}$ syringe. The ether evaporates quickly, leaving the lipophilic compounds on the surface of the plant. Previous work indicates that $>90 \%$ of pachydictyol A remains on the plant after submersion in seawater for $24 \mathrm{~h}$ (Hay and Fenical 1988). Extract-coated portions of Ulva were placed in separate bowls ( $250 \mathrm{~mL}$ seawater $)$ and paired with an equivalent sized control piece of Ulva that had been coated with $300 \mu \mathrm{L}$ of only ethyl ether. A pipette separated the two Ulva portions within each bowl, and a mark was made on the side of the bowl in order to identify treatment vs. control portions. Two to four amphipods from the laboratory cultures (second generation) were added to the bowls, and feeding was allowed for $\sim 48 \mathrm{~h}$, at which time the tissue was blotted dry and reweighed. Three to four autogenic control replicates were set up in a similar manner except that no amphipods were added. From these control tissues, a ratio of $C_{\mathrm{f}}$ to $C_{\mathrm{i}}$ was calculated (see Methods: Feeding assays), and this ratio was used to scale the feeding rates in all amphipod replicates. Separate autogenic controls for each amphipod replicate were not created for several reasons: only one seaweed species was used, very little autogenic change was documented $\left[C_{\mathrm{f}} / C_{\mathrm{i}}\right.$ 
$($ mean $\pm \mathrm{SE})=0.997 \pm 0.002]$, and the amount of time and resources required for additional autogenic controls would have been substantial. Replicates were removed in cases where all amphipods died or feeding was minimal $(<10 \%$ of total mass offered was consumed); this occurred in only five of 61 cases. To directly assess whether the North Carolina and Connecticut adults differed in their tolerance for the extract, a ratio which indicates relative preference was calculated for each seaweed by dividing the feeding rate for extract-coated Ulva by the total feeding rate combining extract-coated plus solvent-coated Ulva. A nonparametric Mann-Whitney test compared ratios among populations.

Because amphipod populations differed in their willingness to feed on the crude lipophilic extract, we partitioned this extract using Florisil (a silica gel altered to enhance its ability to trap chlorophyll [Sep-Pak 3cc Florisil Cartridges, Millipore Company, Milford, Massachusetts, USA]) to achieve a fraction containing the dictyol diterpenes that have been shown to deter feeding by several herbivores in previous assays (Hay et al. 1987, Cronin and Hay 1996a, b, Stachowicz and Hay 1999) and a fraction containing the remainder of the lipids. To achieve this, the DCM:MeOH extract from $200 \mathrm{mg}$ of plant was dissolved in $2 \mathrm{~mL}$ hexane and placed on the Florisil column. The column was rinsed with $4 \mathrm{~mL}$ of hexane and all $6 \mathrm{~mL}$ were collected in a scintillation vial; this comprised fraction 1. Six $\mathrm{mL}$ of 65:35 hexane: ethyl ether were then pulled through into a second scintillation vial; this comprised fraction 2. Six mL of ether were then pulled through and collected: this comprised fraction 3. The hexane fraction contained nonpolar compounds, the hexane: ether fraction contained diterpene alcohols and sterols, and the ether fraction contained more polar compounds like pigments (Cronin et al. 1995; also confirmed for our partition using thin layer chromatography and dictyol standards). We bioassayed fraction 2 separately. Fractions 1 and 3 were combined before bioassays were conducted on them. We thus assessed the effects of the dictyol-containing fraction and the remainder of the lipid-soluble crude extract.

To quantify the concentration of dictyol E and pachydictyol A (the two major diterpenes in D. menstrualis), we used an analytical HPLC system consisting of a Waters 510 solvent pump, a $20 \mu \mathrm{L}$ sample loop, a $4.6 \times 100 \mathrm{~mm}$ silica column with $3 \mu \mathrm{m}$ particle size and $10 \mathrm{~nm}$ pore size (Rainin Instrument, Emmeryville, California, USA) and a Waters 410 Differential Refractometer, all controlled by Millennium 2000 software (Waters Company, Milford, Massachusetts, USA). Peak areas were integrated using the software. We constructed calibration curves using single $20-\mu \mathrm{L}$ injections of $5,10,20$, and $80 \mu \mathrm{g}$ of dictyol $\mathrm{E}$ and pachydictyol A, diluted in $8.5 \%$ HPLC-grade ethyl acetate : trimethylpentane (EtOAc: TMP).

\section{Laboratory-based fitness traits}

To assess the effects of food species on amphipod fitness, juvenile amphipods were isolated on single seaweed species $2 \mathrm{~d}$ after emergence from the brood pouch. They were held on only these foods for $\sim 4 \mathrm{wk}$ ( $25 \mathrm{~d}$ in 1998; $28 \mathrm{~d}$ in 1999). To set-up this experiment, brooding females were left on Sargassum in small petri dishes until juveniles had left the brood pouch. Juveniles from each mother were placed on one of 10 treatments in individual $40 \mathrm{~mL}$ petri dishes. The 10 treatments were: the eight seaweeds that were offered adults in the multiple choice assays, or Enteromorpha (a green seaweed lacking known secondary metabolites), or a starvation control that received no food. A single mother provided one offspring to each treatment. The amphipods were checked daily for deaths and for reproductive maturity of the females. Water was changed every 2-3 d, and food was added to dishes when depleted. Survivorship, size of surviving amphipods at the termination of the experiment (as measured by the straight-line length of the dorsal edge of the first three segments), and days to female maturity were recorded.

In 1998, the offspring of field-collected mothers (i.e., second generation) were raised on Dictyota menstrualis, D. ciliolata, Ulva, Gracilaria, and Fucus. The fitness of these offspring may have been affected by environmental factors that the mother was exposed to in the field or during transport to the IMS laboratory. As evidence of this, Connecticut juveniles died more quickly in no food controls than did North Carolina juveniles (Connecticut, $2.00 \pm 0.12$ number of days alive [mean $\pm 1 \mathrm{SE}$; North Carolina, $3.19 \pm 0.21$ number of days alive; Mann-Whitney test, $P<0.001)$. In 1999 , offspring of mothers reared in a common environment (i.e., third generation) were isolated on $D$. menstrualis, D. ciliolata, Enteromorpha, Codium, Hypnea, and Sargassum. Because strong differences among populations were not seen on the Ulva, Gracilaria, and Fucus diets in 1998 with second generation juveniles, these seaweeds were not tested again in 1999 with third generation juveniles. There was no evidence of stress among Connecticut juveniles in this third generation, as juveniles from North Carolina and Connecticut died at equal rates without food (Connecticut, $3.00 \pm 0.23$ number of days alive; North Carolina, $3.05 \pm 0.20$ number of days alive; Mann-Whitney test, $P=0.937$ ).

To test for an interaction between site and seaweed, we utilized data from the third generation (1999) on Enteromorpha, D. menstrualis, and D. ciliolata because these were the only treatments with sufficient replicates to allow for such tests. All individuals are independent, because each mother provided no more than one offspring to each treatment and all individuals were placed in separate petri dishes. Interactions in the data on survivorship and reproductive maturity of females were determined using $2 \times 2 \times 3 \chi^{2}$ contingency tables. Interactions in the data on growth and matu- 
ration time were determined from a parametric twoway ANOVA on untransformed data, which satisfied assumptions of normality (Shapiro-Wilk $W$ test, $P>$ 0.05 ) and homoscedasticity (Bartlett's test, $P>0.05$; Zar 1996). Survivorship and proportion of females that became reproductive on different seaweeds were compared using a series of $\chi^{2}$ tests. Growth and maturation time were compared among populations on individual seaweeds using $t$ tests on untransformed data; these comparisons satisfied assumptions of normality and homoscedasticity.

\section{Feeding assays: biogeographic comparison}

To assess whether the differences in feeding preference that we found between our initial Connecticut and North Carolina contrasts were site specific or were indicative of a larger biogeographic pattern, we collected populations from three sites in the northeastern United States (Millstone, Connecticut; Jamestown, Rhode Island; Westport, Massachusetts) and three sites in North Carolina (Wilmington; Morehead City; Harker's Island). Sites within a region were at least $21 \mathrm{~km}$ apart and the regions were separated by at least 800 $\mathrm{km}$. In the laboratory, field-collected adults were given a choice between $D$. menstrualis and Ulva in a manner similar to that of multiple choice assays described previously. A paired $t$ test assessed how each population chose between these two seaweeds. To directly assess whether the North Carolina and Connecticut adults differed in their tolerance for $D$. menstrualis, a ratio was calculated for each population by dividing the feeding rate on $D$. menstrualis by the total feeding on $D$. menstrualis plus Ulva. Regions were compared using a Mann-Whitney test.

\section{RESUlts}

\section{Adult feeding assays}

When simultaneously presented with eight seaweeds, adult amphipods from North Carolina had higher affinity for Dictyota menstrualis and lower affinity for the red seaweed species Gracilaria than did adults from Connecticut (Fig. 1). All seaweed genera offered in these multiple choice assays occur in both locations, except for the tropical brown seaweeds in the genus Dictyota (D. menstrualis and D. ciliolata), which occur in North Carolina but not Connecticut.

Field-collected adults from Connecticut preferentially consumed Codium, Hypnea, and Gracilaria, avoided D. ciliolata and Fucus, and fed at intermediate rates on D. menstrualis, Sargassum, and Ulva (Fig. 1a). Field-collected adults from North Carolina preferred Codium, Hypnea, and D. menstrualis, avoided Ulva, D. ciliolata, and Fucus, and consumed Gracilaria and Sargassum at intermediate rates. Direct tests on relative consumption of individual seaweeds indicate that fieldcollected North Carolina individuals ate proportionately more $D$. menstrualis $(P=0.001)$ than did Con- necticut individuals. There was a nonsignificant trend for Connecticut individuals to eat proportionately more of the red seaweed Gracilaria than did North Carolina individuals.

Crudely similar patterns of differential feeding were detected among second generation amphipods from each location raised since birth in the laboratory and fed only seaweeds from North Carolina. Second generation Connecticut adults consumed proportionately more Gracilaria and proportionately less D. menstrualis than did second generation North Carolina adults (Fig. 1b). Interestingly, Codium was strongly preferred by field-collected Connecticut and North Carolina individuals but not by second generation individuals; however, it is unlikely that this difference between generations toward Codium indicates strong maternal effects on feeding preference since Codium grazed within the experimental bowls appeared to degrade more rapidly than autogenic control plants during the course of the 1998 assay, possibly giving a false appearance of tissue loss due to feeding.

When isolated with one of seven seaweed species from North Carolina in no-choice assays, field-collected adults from Connecticut and North Carolina fed at similar rates (Fig. 2a). There was no interaction in feeding rate between site and seaweed species (ANOVA on log-transformed data; Site, df $=1$, MS $=$ $0.279, F=11.79, P<0.001$; Seaweed, $\mathrm{df}=6$, $\mathrm{MS}=$ $0.730, F=30.87, P<0.001$; Site $\times$ Seaweed, df $=$ 6 , MS $=0.033, F=1.39, P=0.226)$. The significant main effect of site was probably caused by the larger individuals from Connecticut eating more total food per amphipod (E. E. Sotka, personal observation). For both populations, feeding rates were strongly and negatively correlated with the ash-free dry mass per volume for each seaweed (Fig. 2b; $r^{2}=0.84$ and 0.93 for $\mathrm{CT}$ and NC populations respectively; $P<0.004$ for both), indicative of a compensatory feeding response (Slansky 1992, Cruz-Rivera and Hay 2000, 2001). There was no significant difference in slope nor elevation between regressions for the two populations $(P$ $>0.50$ for each comparison; Zar 1996).

\section{Bioassay guided fractionation of Dictyota extracts}

Defensive metabolites produced by Dictyota menstrualis deter Connecticut amphipods more than North Carolina amphipods (Fig. 3). When offered a choice between fresh Ulva coated with natural concentrations of the crude lipophilic extract (i.e., DCM:MeOH fraction) from D. menstrualis vs. fresh Ulva coated with solvents only, amphipods from North Carolina consumed $65 \%$ more extract-coated Ulva than did amphipods from Connecticut (Fig. $3, P=0.048$ ). This lipophilic extract was further purified by chromatography into fractions containing the diterpene alcohols and the remainder of the extract. When compared to amphipods from Connecticut, North Carolina amphipods consumed more than twice as much of the diterpene- 
a) 1998 , field-collected adults

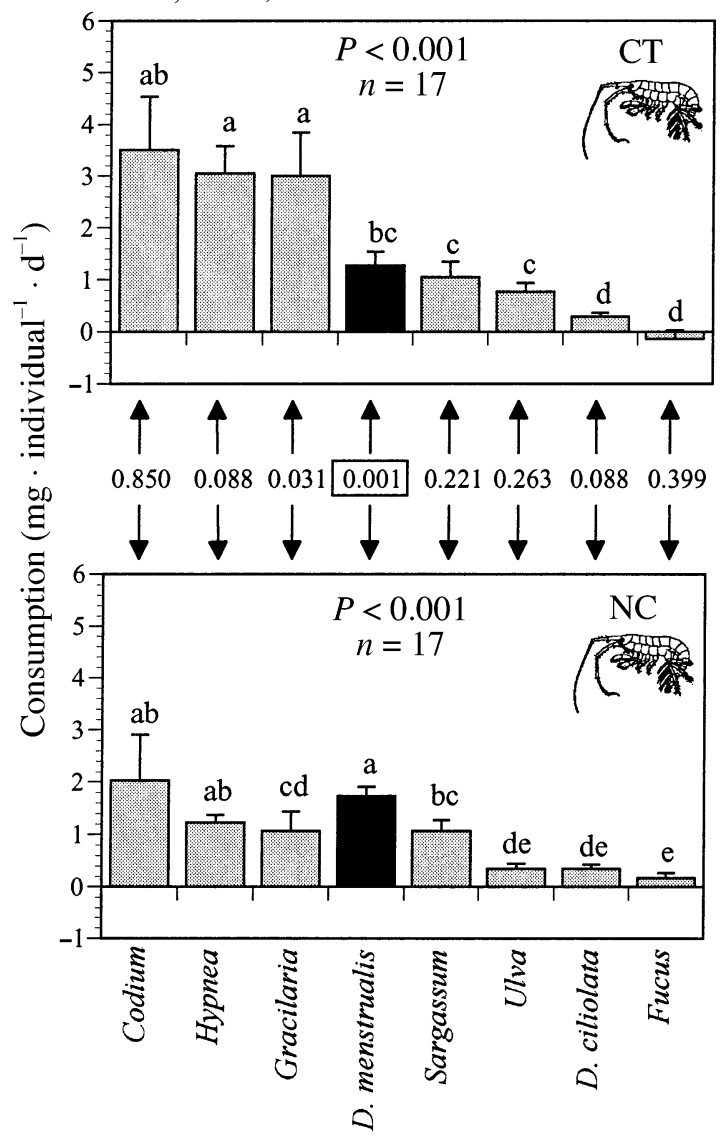

b) 1999 , second generation adults

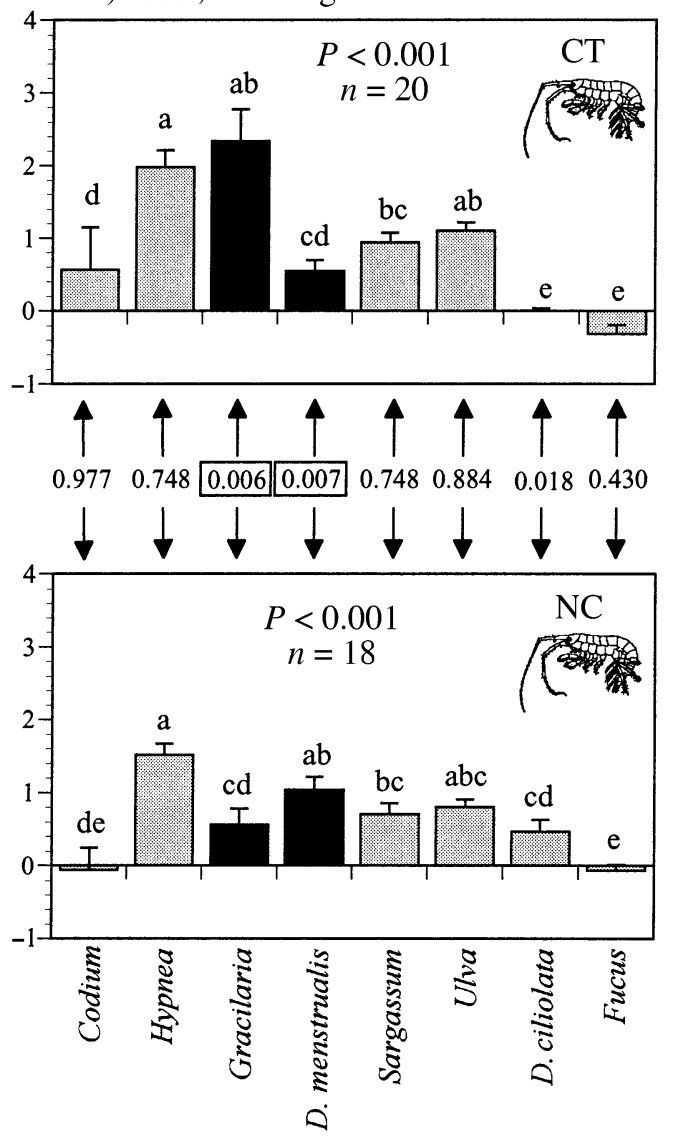

FIG. 1. Multiple choice feeding assay for Ampithoe longimana individuals from Connecticut and North Carolina (mean +1 SE): (a) assay using field-collected adults (1998) and (b) assay using second generation adults (1999). The nonparametric Friedman's test was used for the overall test and for pairwise differences among seaweeds in tissue consumption (see Methods). Numbers between the graphs indicate $P$ values from a Mann-Whitney test, examining the difference between Connecticut and North Carolina in the proportion of total amount consumed for each seaweed. Boxed $P$ values indicate seaweeds for which significant differences in relative consumption were detected, after sequential Bonferroni adjustments (following Rice 1989).

treated Ulva $(P=0.026)$. There was no difference between the two populations in behavior toward the other fraction $(P=0.52)$. Note that in every assay, North Carolina and Connecticut populations each ate significantly more solvent-coated Ulva than extract-coated Ulva (i.e., all means are $<0.5$; crude, diterpenoid, and nonditerpenoid fractions; paired $t$ test, $P<0.05$ for each assay). The two most abundant diterpene alcohols in $D$. menstrualis were present at relatively low natural concentrations $(0.010 \pm 0.005 \%$ dictyol $\mathrm{E}$, by wet mass [mean $\pm 1 \mathrm{SE}, n=8] ; 0.007 \pm 0.001 \%$ pachydictyol $\mathrm{A}$, by wet mass $[n=7])$, compared with previously determined values for North Carolina populations of this plant (Cronin et al. 1995, Cronin and Hay 1996a, b).

\section{Laboratory-based fitness traits}

Second generation amphipods from North Carolina exhibited significantly higher survivorship on Dictyota menstrualis than did Connecticut amphipods, but there was no difference in survivorship on the plant in third generation contrasts (Fig. 4a). In contrast to these inconsistent differences in survivorship on D. menstrualis (Fig. 4a), the North Carolina population consistently exhibited higher growth (Fig. 4b), more reproductive females (Fig. 4c), and fewer days to reproductive maturity (Fig. 4d) on Dictyota menstrualis and D. ciliolata than did the Connecticut population. There were few differences between Connecticut and North Carolina amphipods in fitness on seven other seaweeds tested.

Survivorship of $A$. longimana varied across seaweed species, with the Connecticut and North Carolina populations surviving at crudely similar rates (Fig. 4a). Both populations showed relatively high survivorship on D. menstrualis and D. ciliolata (between $65 \%$ and $100 \%$ in 1998 and $76 \%$ and $87 \%$ in 1999) and Enteromorpha (between $68 \%$ and $76 \%$ in 1999), and had relatively low survivorship on other seaweeds (between $0 \%$ and $50 \%$ ). Direct statistical comparisons on treatments with high sample size (i.e., third generation in- 


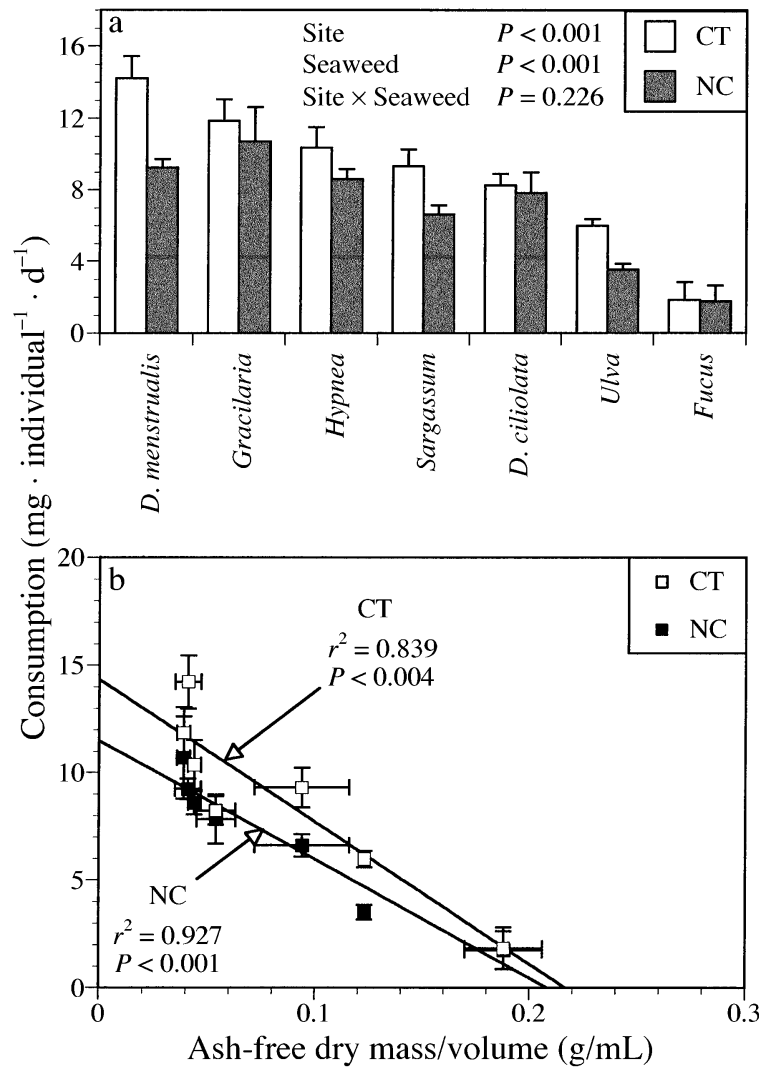

FIG. 2. No choice feeding assay for adult amphipods from Connecticut and North Carolina plotted (a) as a function of seaweed species (mean $+1 \mathrm{SE}$ ) and (b) as a function of ashfree dry mass of each seaweed species (mean $\pm 1 \mathrm{SE}$ ). A twoway ANOVA revealed significant effects of site and seaweed species on feeding rate, but no significant interaction [see $P$ values on in panel (a)]. The $r^{2}$ and $P$ value for best-fit lines are indicated in panel (b).

dividuals in 1999 on D. menstrualis, D. ciliolata, and Enteromorpha) indicate no interaction between seaweed species, site and state (i.e., alive or dead) at 28 $\mathrm{d}\left(\chi^{2}=3.141\right.$, df $\left.=7, P>0.75\right)$. Second generation Connecticut individuals had significantly lowered survivorship on D. menstrualis and Fucus than did second generation North Carolina individuals, while differences in the survivorship of third generation North Carolina and Connecticut individuals were not detected on any seaweed offered (Fig. 4a). It is unclear why North Carolina and Connecticut individuals differed in survivorship on $D$. menstrualis in the second generation (1998), but not the third generation.

Growth of surviving North Carolina individuals was significantly faster than that of Connecticut individuals on D. menstrualis and D. ciliolata in both generations, and there was no significant difference in growth on any other seaweed (Fig. 4b). Highest growth rates for both populations were on $D$. menstrualis, $D$. ciliolata, and Enteromorpha. Second generation North Carolina individuals were $13 \%$ and $16 \%$ larger than second gen- eration Connecticut individuals on $D$. menstrualis and D. ciliolata (respectively) after $25 \mathrm{~d}$, while third generation North Carolina individuals were $24 \%$ and $28 \%$ larger than third generation Connecticut individuals on D. menstrualis and D. ciliolata (respectively) after 28 d (Fig. 4b). There was no detectable difference in size on Enteromorpha, or on any other seaweed offered. A two-way ANOVA on treatments with high sample sizes (i.e., using third generation individuals on D. menstrualis, D. ciliolata, and Enteromorpha) indicated a significant interaction between site and seaweed (ANOVA; Site, $\mathrm{df}=1$, MS $=292.17, F=33.20, P<0.001$; Seaweed, $\mathrm{df}=2$, MS $=949.66, F=107.90, P<0.001$; Site $\times$ Seaweed, $\mathrm{df}=2$, MS $=58.93, P=0.002$ ).

A significantly greater proportion of North Carolina females than Connecticut females became mature on D. menstrualis and D. ciliolata, and there was no significant difference among the populations on any other seaweed (Fig. 4c). Nearly all second and third generation North Carolina females reproduced on D. menstrualis and D. ciliolata (31 out of 33 females total), while only $0 \%$ and $14 \%$ of second generation Connecticut females and $27 \%$ and $33 \%$ of third generation Connecticut females reproduced on D. menstrualis and D. ciliolata, respectively ( 7 out of 31 females total; Fig. 4c). There was no significant difference between Connecticut and North Carolina populations in the proportion of reproductive females on Sargassum or on

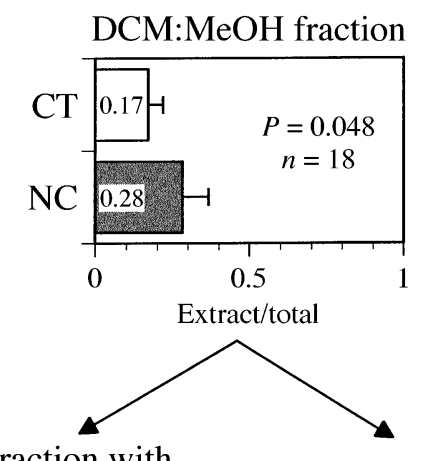

Fraction with diterpene alcohols

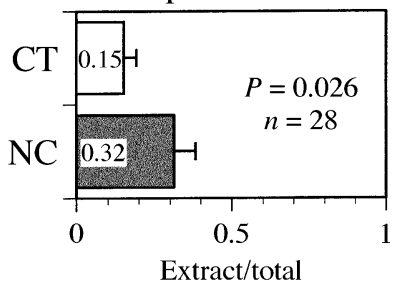

Remainder of extract

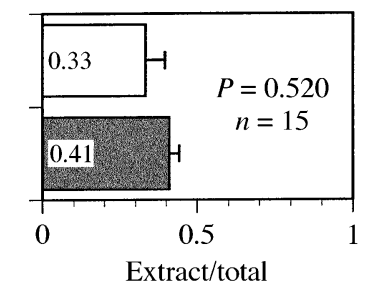

FIG. 3. Bioassay-guided fractionation of Dictyota menstrualis extracts, and their effects on feeding by Connecticut (CT) and North Carolina (NC) populations. The ratio of extract-coated Ulva consumed to total amount consumed (i.e., extract-coated and solvent-coated Ulva combined) within each replicate is indicated for each population for each fraction (mean $\pm 1 \mathrm{SE}$ ). A nonparametric Mann-Whitney test was used to test for differences. Abbreviations are: DCM, dichloromethane; $\mathrm{MeOH}$, methanol. 
a) Survivorship

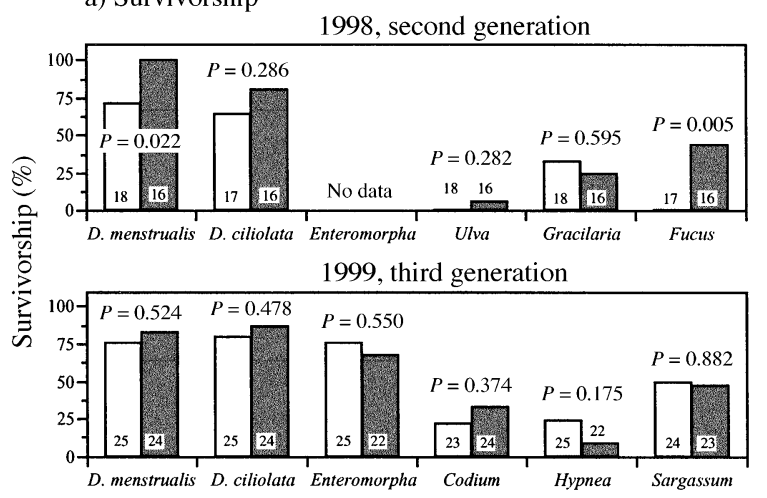

c) Reproductive females (\%)

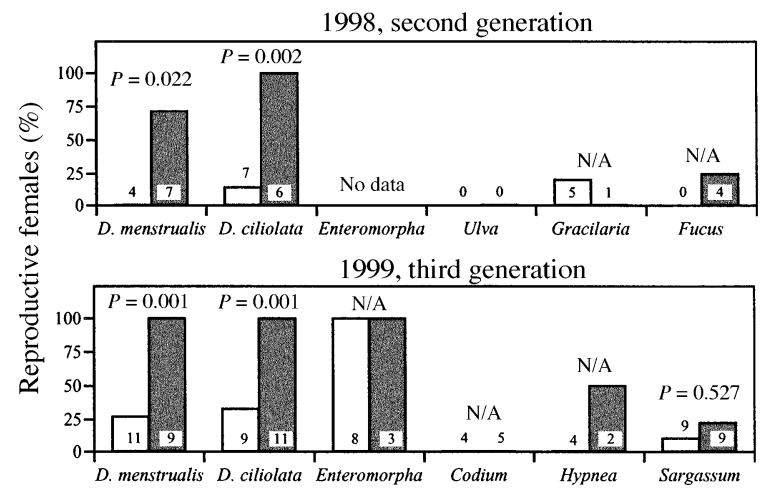

b) Growth

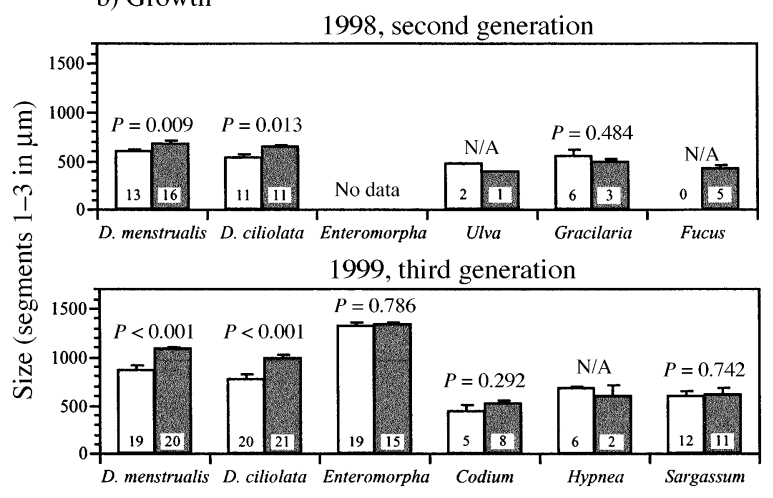

d) Days to maturity

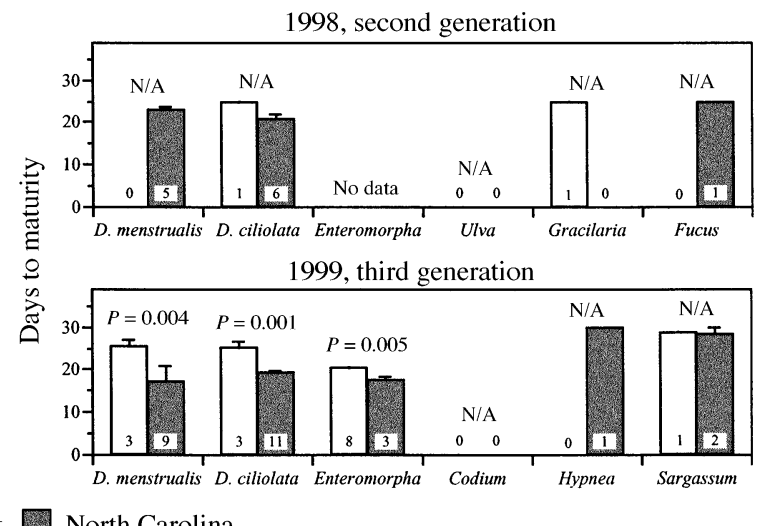

FIG. 4. Fitness of Ampithoe longimana individuals from Connecticut and North Carolina on nine seaweeds. (a) Survivorship of second generation individuals (1998) after $25 \mathrm{~d}$ and of third generation individuals (1999) after $28 \mathrm{~d}$. $P$ values are generated by $\chi^{2}$. Contingency table analysis of Dictyota menstrualis, D. ciliolata, and Enteromorpha data from 1999 indicate that there is no interaction between seaweed and site (see Results). (b) Size (mean $+1 \mathrm{SE}$ ) of surviving second generation individuals (1998) after $25 \mathrm{~d}$ and third generation individuals (1999) after $28 \mathrm{~d}$. $P$ values are generated from unpaired $t$ tests. A two-way ANOVA of $D$. menstrualis, D. ciliolata, and Enteromorpha data from 1999 indicates a significant interaction between site and seaweed (see Results). (c) The proportion of females in the second generation (1998) that were reproductive after $25 \mathrm{~d}$ and the proportion of females in the third generation (1999) that were reproductive after $28 \mathrm{~d}$. $P$ values are generated by $\chi^{2}$. Contingency table analysis of $D$. menstrualis, D. ciliolata, and Enteromorpha data from 1999 indicates a significant interaction between seaweed and site (see Results). Because all females on Enteromorpha (1999) reproduced, no statistical test was performed. (d) Days to reproductive maturity (mean $+1 \mathrm{SE})$ for the second generation (1998) and for the third generation (1999). $P$ values are generated from unpaired $t$ tests. A twoway ANOVA of D. menstrualis, D. ciliolata, and Enteromorpha data from 1999 indicates a nearly significant $(P<0.06)$ interaction between site and seaweed (see Results). For a-d, comparisons with "N/A" were not tested statistically because of small sample size.

Enteromorpha. A contingency table analysis using third generation individuals raised on $D$. menstrualis, D. ciliolata, and Enteromorpha documents dependence among seaweed species, site, and reproductive state $\left(\chi^{2}\right.$ $=32.413$, df $=7, P<0.001)$.

North Carolina females reached reproductive maturity in considerably less time than Connecticut females on D. menstrualis and D. ciliolata (Fig. 4d). On average, third generation North Carolina females reproduced $8.5 \mathrm{~d}$ and $6.1 \mathrm{~d}$ sooner than Connecticut females on D. menstrualis and D. ciliolata, respectively, and only 2.7 d sooner on Enteromorpha (Fig. 4d). In general, North Carolina females became gravid at about the same time whether feeding on Enteromorpha or either of the Dictyota species. In contrast, Connecticut females matured more slowly on both of the Dictyota species compared to their maturation rate when feeding on Enteromorpha. This dependence of site differences on seaweed species is indicated by a nearly significant interaction term (ANOVA; Site, df $=1$, MS $=223.28$, $F=38.11, P<0.001 ;$ Seaweed, $\mathrm{df}=2, \mathrm{MS}=25.97$, $F=4.43, P=0.020 ;$ Site $\times$ Seaweed, $\mathrm{df}=2$, MS $=$ $18.37, F=3.14, P=0.058)$. This estimate of relative reproductive fitness is conservative, because it excludes the numerous Connecticut females that did not reproduce at all within $28 \mathrm{~d}$.

\section{Juvenile feeding assay}

When isolated on a single seaweed, North Carolina juveniles ate more $D$. menstrualis than did Connecticut 


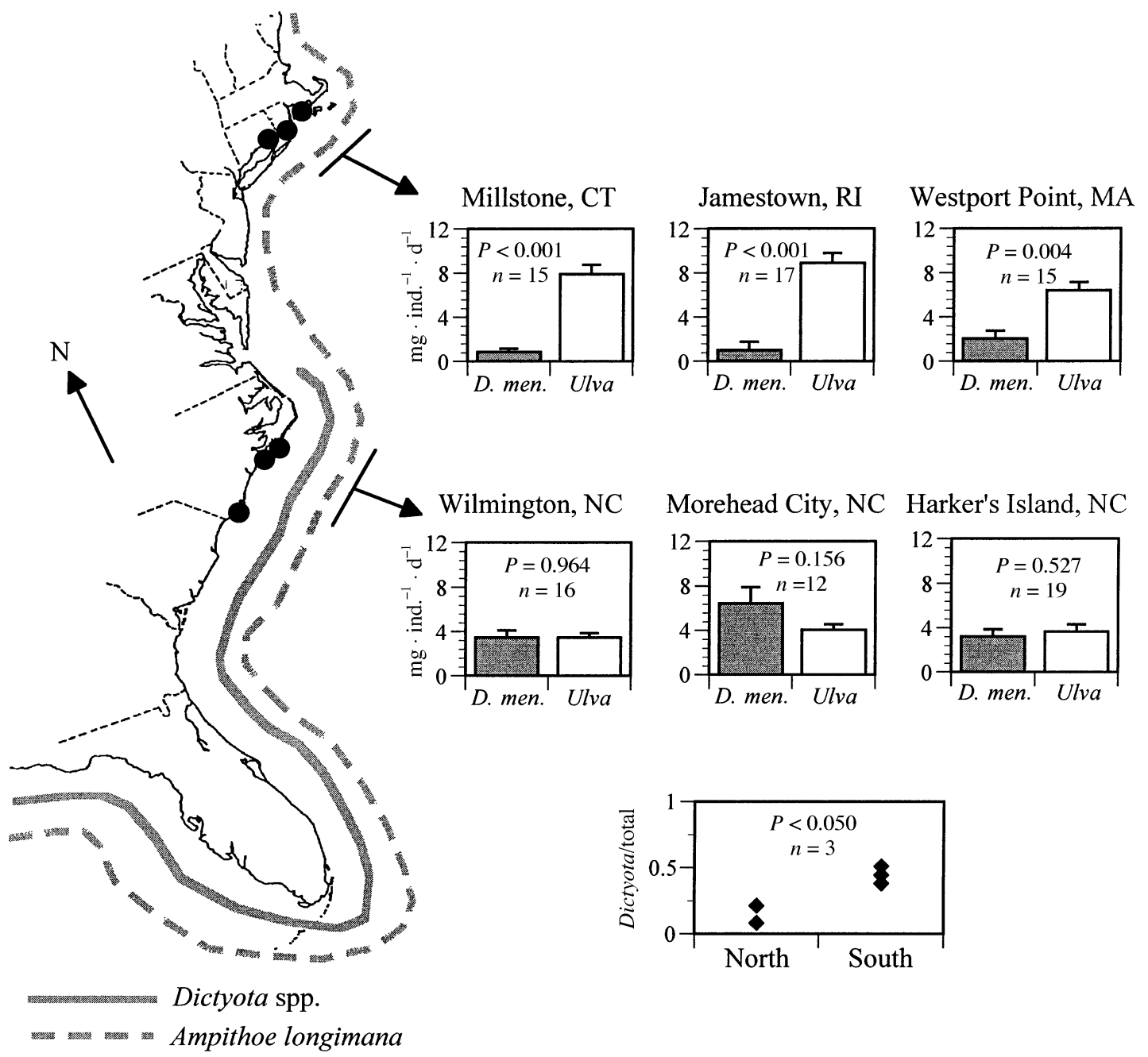

FIG. 5. Feeding assay (mean $+1 \mathrm{SE}$ ) for Ampithoe longimana individuals from six populations. Each population was given a choice between Ulva sp. and Dictyota menstrualis. $P$ values for each were generated from paired $t$ tests. A nonparametric MannWhitney test indicated that southern populations consumed proportionately more $D$. menstrualis than did northern populations.

juveniles, while the two populations consumed Enteromorpha at rates that were statistically indistinguishable (milligrams consumed per scaled individual per day $[$ mean $\pm 1 \mathrm{SE}] ;$ D. menstrualis: $\mathrm{CT}=0.157 \pm$ $0.011, \mathrm{NC}=0.237 \pm 0.021 ;$ Enteromorpha: $\mathrm{CT}=$ $0.234 \pm 0.028, \mathrm{NC}=0.226 \pm 0.033)$. The significant interaction between site and seaweed species $(\mathrm{df}=1$, $\chi^{2}=4.033, P=0.045$ ) was indicated by a MannWhitney test on the absolute difference between populations in scaled feeding rate for each seaweed.

\section{Biogeographic pattern in tolerance to Dictyota}

Differences among the North Carolina and Connecticut populations in tolerance for Dictyota are indicative of regional differences and not restricted to the particular locations from which we made our initial collections. When given a choice between the seaweeds Ulva and D. menstrualis, three populations from the northeastern United States (collected from Connecti- cut, Rhode Island, and Massachusetts) consumed significantly more Ulva than $D$. menstrualis $(P<0.004$ for all three populations, Fig. 5). In contrast, individuals collected from three locations within North Carolina consumed Ulva and D. menstrualis at rates that were statistically indistinguishable (Fig. 5). A direct statistical evaluation revealed that populations from North Carolina consumed proportionately more $D$. menstrualis than populations from the northeastern U.S. coastline (as measured by amount of D. menstrualis consumed relative to the total amount of both seaweeds consumed; Fig. 5).

\section{DISCUSSION}

A North Carolina population of the amphipod Ampithoe longimana that is sympatric with tropical seaweeds in the genus Dictyota more readily feeds on Dictyota menstrualis (Figs. 1 and 5), has higher fitness on D. menstrualis and D. ciliolata (Fig. $4 \mathrm{~b}-\mathrm{d}$ ), and is 
less affected by Dictyota's secondary metabolites (Fig. 3 ) than a Connecticut population of A. longimana from beyond Dictyota's geographic range. To our knowledge, this represents the first time that population-level variation in adult feeding preference for, and juvenile performance on, seaweeds has been demonstrated for a marine herbivore, but such patterns have rarely been investigated in marine systems. Within-population variation in preference and performance among marine herbivores has been documented previously, but evidence for local genetic differentiation in these traits has not (e.g., Duffy and Hay 1991, Guarna and Borowsky 1993, Poore and Steinberg 2001). Further, Ampithoe longimana should be added to the small but growing number of herbivores that reveal substantial adaptation to local floral communities despite their strongly polyphagous feeding habits. Such relationships have been shown previously for terrestrial herbivores (lepidopterans [Thompson 1994], grasshoppers [e.g., Sword and Dopman 1999], seed beetles [e.g., Fox et al. 1994], and mammals [e.g., Mangione et al. 2000]).

Several lines of evidence indicate that the geographic variation in herbivore preferences has a genetic basis. First, because amphipods in North Carolina were never collected from Dictyota species or during times of the year when Dictyota was most abundant, recent feeding history is unlikely to explain patterns in feeding preferences (cf. Trowbridge 1991). Second, differences in adult preference for $D$. menstrualis were consistent between field-collected individuals and second generation individuals that were raised in a common environment (Fig. 1). Third, differences in tolerance for D. menstrualis metabolites (Fig. 3) and juvenile feeding behavior were found using individuals cultured in a common environment. Finally, laboratory rearing assays indicate that feeding preference for $D$. menstrualis is heritable and under polygenic control in a largely additive manner (E. E. Sotka, unpublished data).

As with variation in adult feeding preferences, geographic variation in the fitness of juvenile amphipods feeding on Dictyota species likely has a genetic basis. Offspring of field-collected mothers (Fig. 4b-d; see 1998, second generation) and offspring whose mothers were raised in the laboratory (Fig. 4b-d; see 1999, third generation) showed parallel responses to being isolated with the two Dictyota species. These differences in fitness are due, at least in part, to genetic differences among juveniles in the behavioral acceptance of Dictyota. Whether the populations also differ in their physiological capability to detoxify secondary metabolites will need to be assessed with further experiments.

\section{Chemical mediation of geographic variation}

Geographic variation in preference for Dictyota menstrualis is mediated by tolerance for the secondary metabolites this alga produces. Though both amphipod populations were deterred by the lipophilic fraction containing diterpene alcohols, the Connecticut population was more strongly deterred than the North Carolina population (Fig. 3). Similarly, variation among different species of consumers in feeding preference for Dictyota is mediated by the same diterpenoid fraction or compounds (Hay et al. 1987, Duffy and Hay 1994, Cronin and Hay 1996b).

The two major diterpene alcohols in the extract, dictyol $\mathrm{E}$ and pachydictyol A, were present in our samples at relatively low natural concentrations (e.g., $0.01 \%$ dictyol $\mathrm{E}$ by wet mass). That North Carolina adults were deterred by these low concentrations was surprising, given that previous work indicated that North Carolina populations were unresponsive toward low concentrations and deterred only by relatively high natural concentrations (e.g., $0.06 \%$ dictyol E by wet mass; Cronin and Hay 1996a). However, our extracts were coated directly onto fresh Ulva blades, while Cronin and Hay added extracts to a finely powdered, freezedried mixture of three green seaweeds (Ulva, Enteromorpha, and Cladophora), which were then embedded in an agar matrix. Our method may concentrate the extract on the surface of fresh Ulva blades where the amphipod first encounters the plant. Further, fresh Ulva may be a lower quality food than the mixture of freezedried seaweeds used by Cronin and Hay; changes in quality of the test food alone can affect the acceptability of an extract (cf. Duffy and Paul 1992).

Because our bioassay-guided fractionation was halted due to a lack of material, we are not certain of the specific compounds that mediate population-level differences in tolerance. Bioassays using the agar-based method indicate that the populations do not differ in behavior when offered dictyol E or pachydictyol A singly at natural concentrations (E. E. Sotka, unpublished data). It is possible that a combination of these diterpenes act synergistically, or that the deterrent fraction we tested contains compounds other than these two diterpenes that are differentially tolerated by our populations.

As an aside, the feeding rates of adult A. longimana when isolated with a single species of seaweed are characterized by a compensatory feeding response (Fig. 2; Slansky 1992, Cruz-Rivera and Hay 2000, 2001). It is interesting that Connecticut adults will readily feed on Dictyota species when the alternative is starvation, but when offered a choice (i.e., when feeding preference is assayed), adults from Connecticut avoid consuming Dictyota (see Figs. 1 and 5). This suggests that the feeding behavior of $A$. longimana adults is a complex, context-dependent process that is strongly responsive to the density of organic material (Fig. 2) and secondary metabolites (Fig. 3), among other factors (also see Duffy and Hay 1991, 1994, Cruz-Rivera and Hay 2000, 2001). Such complexity is clearly not limited to this arthropod species (Bernays and Chapman 1994, Hay et al. 1994). 


\section{Performance trade-offs and the evolution of a generalist lifestyle}

In contrast to the prevalence of host specialization among herbivorous insects (Bernays and Chapman 1994), the vast majority of marine herbivores are generalists (Hay 1992). Several pressures in the oceans favor the evolution of polyphagy, including spawned offspring subject to the vagaries of oceanographic dispersal, the strong seasonality to seaweed communities, the lack of a diapause stage, and the more equal generation times of herbivores and their hosts (Hay and Steinberg 1992). All of these phenomena reduce the ability of individuals to specialize on particular hosts and likely select for the utilization of available, as well as preferred, hosts. Further, consumer specialization can be opposed by the benefits of a mixed diet that satisfies nutritional needs or minimizes toxic effects of compounds from any single plant (Pennings et al. 1993, Bernays et al. 1994, Dearing et al. 2000).

An alternative, though not mutually exclusive, hypothesis for the maintenance of a generalist lifestyle among marine herbivores is that there are no strong performance trade-offs in the use of alternative seaweeds, a force hypothesized to drive specialization among terrestrial insects (Dethier 1954). Specialists are favored when traits providing fitness benefits on one seaweed negatively correlate with traits providing benefits on alternative seaweeds or on a suite of seaweeds. Whether this process plays an important role in driving specialization among terrestrial insects is equivocal, largely because tests designed to detect trade-offs have been either successful (e.g., Rausher 1984, Fry 1990, Traxler and Joern 1999), unsuccessful (e.g., Hare and Kennedy 1986, Futuyma 1991, Thompson 1996), or too biased to interpret (Rausher 1988; see reviews by Via 1990, Bernays and Chapman 1994).

Though our results are preliminary, it appears that no strong performance trade-offs occur with A. longimana among the host plants we tested. Higher feeding-based fitness for Dictyota by North Carolina juveniles did not translate to lower fitness on any other seaweed offered (Fig. 4b-d), including the brown seaweed Fucus vesiculosus, whose chemical extracts can deter amphipod feeding (M. Deal, personal communication). In fact, higher tolerance for $D$. menstrualis correlates consistently with higher tolerance for $D$. ciliolata, a response not uncommon among genotypes confronted with chemically similar plants (e.g., Hare and Kennedy 1986, Feeny 1991). Thus, the lack of strong performance trade-offs in A. longimana indicates this potentially strong selective force driving specialization is not present within A. longimana-seaweed interactions. If true for other marine plant-herbivore interactions, this phenomenon could help explain the dominance of the generalist lifestyle among marine herbivores.

There are several reasons why such an interpretation should be made with caution (Rausher 1988). First, we may not have been able to detect trade-offs because we did not pick the correct seaweeds. We could not for practical reasons test all seaweeds that northern and southern populations used. Further, though there are several species that only the northern populations would encounter (e.g., the laminarian kelps Agarum sp. and Laminaria sp.), these species rarely supported $A$. longimana populations (E. E. Sotka, personal observation). Future work should identify the hosts that northern populations use most and test for trade-offs between Dictyota and those plants. Second, our power may not be strong enough to detect small trade-offs. For instance, though there was a threefold difference in survivorship between North Carolina and Connecticut juveniles on Hypnea ( $8 \%$ vs. $24 \%$ ), this was nonsignificant by contingency table analysis (Fig. 4a). Our power was sufficient to detect differences in growth and reproductive fitness on Dictyota, and there were no population-level differences in these traits on Hypnea (Fig. 4b-d), indicating that if trade-offs with these seaweeds exist, they are asymmetric. Third, a more robust test of trade-offs is to test for within-population (co)variance in fitness on alternate seaweeds (cf. Via $1984 a, b)$, an approach we did not take in this study. Fourth, we may have neglected to measure fitness components that reveal trade-offs (e.g., egg size, egg number). This seems unlikely, as many, though not all (Fig. 4a; Cruz-Rivera and Hay 2001), fitness components are correlated (Fig. 4b-d; Nelson 1980b). Finally, laboratory estimates of fitness may not translate under field conditions, if factors other than plant quality drive individual reproductive fecundity.

In contrast to the lack of performance trade-offs in A. longimana, trade-offs may be common among molluscan grazers (Steneck and Watling 1982). Feedingbased apparatuses that efficiently remove one type of seaweed (e.g., tough, leathery tissues) inefficiently remove other types of seaweed (e.g., filamentous tissues; see also Padilla 1985), a process which may be at least partially responsible for the specialized host use among sea slugs and some limpets on larger seaweeds (Vermeij 1992, Williams and Walker 1999). Thus, it is possible that performance trade-offs based on tolerance to seaweed chemicals could be rare, while trade-offs mediated by seaweed structure could be more common. Future work in this area should directly manipulate plant morphology and chemistry, because large seaweeds on which several marine herbivores specialize are both chemically rich and structurally resistant (Hay et al. 1994, Schupp and Paul 1994).

\section{Evolution of marine plant-herbivore interactions}

Since population-level differences in herbivore tolerance have a genetic basis (Figs. 1 and 4), and are general to several populations either inside or outside the range of Dictyota (Fig. 5), it is clear that A. longimana responds evolutionarily to the local availability 
of this chemically rich seaweed. This result has several implications for the study of marine plant-herbivore interactions. First, the presence of local adaptation in A. longimana indicates that seaweeds and their selective environment can play fundamental roles in the evolution of feeding preferences of marine herbivores. These selective forces are sometimes strong enough to maintain local genetic differentiation in the face of substantial gene flow (E. E. Sotka, J. P. Wares, and M. E. Hay, unpublished manuscript). Further, such selection likely operates across both micro- and macroevolutionary timescales; a small number of studies using species-level, rather than population-level comparisons have detected biogeographic patterns in herbivore tolerance for the metabolites of local seaweeds (e.g., Steinberg et al. 1995, Cronin et al. 1997).

Second, the results are also consistent with the hypothesis that the selective pressure to avoid predators can maintain host preferences in small herbivores (Hay et al. 1987, Hay 1992). Previous work in this system has repeatedly shown that omnivorous fishes avoid foraging on Dictyota and that mesograzers such as A. longimana, gain protection by associating with Dictyota (Hay et al. 1987, Duffy and Hay 1991, 1994, Stachowicz and Hay 1999). Small herbivores that cannot utilize Dictyota can decline or become locally extinct in habitats with high fish abundances, while A. longimana persists or even increases in abundance (Duffy and Hay 1994). It is likely that this same predator pressure acts to increase mean preference for Dictyota within populations of $A$. longimana by selecting against those genotypes with lower preference.

Third, the evolution of $A$. longimana preference for chemically rich Dictyota species may either represent sequential evolution (Jermy 1984, Arrontes 1999) or be part of a diffuse coevolutionary cycle (Janzen 1980, Vermeij 1987). To separate the two alternatives will require evidence that $A$. longimana can drive the evolution of Dictyota chemical defenses, and despite ample indirect evidence (e.g., Duffy and Hay 1994, 2000, Cronin and Hay 1996a), there have been no direct tests for such selection in this or any other marine plantherbivore system (cf. Simms and Rausher 1993, Mauricio and Rausher 1997). Even among relatively wellstudied, vascular plant-insect systems, the role that small grazers play in driving the fitness of their hosts is contentious (Crawley 1997).

In summary, geographic variation in ecologically relevant traits, like consumer preference or prey defense, may be the rule rather than the exception, largely because many biotic interactions have players with dissimilar geographic distributions (e.g., Stanhope et al. 1993, Bolser and Hay 1996, Stachowicz and Hay 2000). Such variation is not only a useful lens through which one can gain insight into the ultimate and proximate causes of microand macroevolutionary change (Foster 1999), but geographic variation also can have profound consequences for the ecology and evolution of local consumer-prey interactions (Thompson 1994, Travis 1996).

In the present case, geographic variation in tolerance for seaweed chemical defenses has yielded insight into selective forces that act on the feeding preferences of this, and perhaps other, marine herbivores. Previous marine investigations have evaluated geographic patterns of seaweed resistance to herbivores (e.g., Steinberg et al. 1995, Bolser and Hay 1996), but few have evaluated how herbivore populations respond to this variance (e.g., Stachowicz and Hay 2000), and none have assessed the fitness-based consequences or the genetic basis underlying these interactions. Given the powerful insights derived from such studies in terrestrial systems (Fritz and Simms 1992, Bernays and Chapman 1994) and the striking contrasts and parallels between marine and terrestrial systems (Hay and Steinberg 1992), it is likely that additional marine investigations would be rewarding.

\section{ACKNOWLEDGMENTS}

Funding was provided by an NSF Dissertation Improvement Grant (IBN-0073073), Theodore Roosevelt Memorial Fund of the American Museum of Natural History, and a Paul Hardin Dissertation Completion Fellowship to E. E. Sotka, by NSF grants OCE 95-29784 to M. E. Hay, and by the Harry and Linda Teasley Endowment to the Georgia Institute of Technology. Thanks to Jay Stachowicz and Rachael Wagaman for logistical help, Niels Lindquist and Bob Whitlatch for generously offering lab space, and Pete Peterson, David Pfennig, Mark Rausher, Larry Crowder, Graham Forrester, and two anonymous reviewers for helpful critiques.

\section{Literature Cited}

Arrontes, J. 1999. On the evolution of interactions between marine mesoherbivores and algae. Botanica Marina 42:137155.

Berenbaum, M. R., C. Favret, and M. A. Schuler. 1996. On defining "key innovations" in an adaptive radiation: cytochrome p450s and Papilionidae. American Naturalist 148: S139-A155.

Berenbaum, M. R., and A. R. Zangerl. 1998. Chemical phenotype matching between a plant and its insect herbivore. Proceedings of the National Academy of Sciences 95:1374313748.

Bernays, E. A., K. L. Bright, N. Gonzalez, and J. Angel. 1994. Dietary mixing in a generalist herbivore: tests of two hypotheses. Ecology 75:1997-2006.

Bernays, E. A., and R. F. Chapman. 1994. Host-plant selection by phytophagous insects. Chapman and Hall, New York, New York, USA.

Bolser, R. C., and M. E. Hay. 1996. Are tropical plants better defended? Palatability and defenses of temperate vs. tropical seaweeds. Ecology 77:2269-2286.

Bousfield, E. L. 1973. Shallow-water Gammaridean Amphipoda of New England. Comstock, Ithaca, New York, USA.

Bush, G. L. 1994. Sympatric speciation in animals: new wine in old bottles. Trends in Ecology and Evolution 9:285-288.

Crawley, M. J. 1997. Plant-herbivore interactions. Pages 401474 in M. J. Crawley, editor. Plant ecology. Second edition. Blackwell Scientific, Oxford, UK.

Cronin, G., and M. E. Hay. 1996a. Induction of seaweed chemical defenses by amphipod grazing. Ecology 77:2287-2301.

Cronin, G., and M. E. Hay. 1996b. Susceptibility to herbivores depends on recent history of both plant and animal. Ecology 77:1531-1543.

Cronin, G., N. Lindquist, M. E. Hay, and W. Fenical. 1995. Effects of storage and extraction procedures on yields of li- 
pophilic metabolites from the brown seaweeds Dictyota ciliolata and D. menstrualis. Marine Ecology Progress Series 119:265-273.

Cronin, G., V. J. Paul, M. E. Hay, and W. Fenical. 1997. Are tropical herbivores more resistant than temperate herbivores to seaweed chemical defenses? Diterpenoid metabolites from Dictyota acutiloba as feeding deterrents for tropical versus temperate fishes and urchins. Journal of Chemical Ecology 23:289-302.

Cruz-Rivera, E., and M. E. Hay. 2000. Can quantity replace quality? Food choice, compensatory feeding, and fitness of marine mesograzers. Ecology 81:201-219.

Cruz-Rivera, E., and M. E. Hay. 2001. Effects of macroalgal traits on the feeding and fitness of an herbivorous amphipod: the relative importance of selectivity, mixing, and compensation. Marine Ecology Progress Series 218:249-266.

Dearing, M. D., A. M. Mangione, and W. H. Karasov. 2000. Diet breadth of mammalian herbivores: nutrient versus detoxification constraints. Oecologia 123:397-405.

Dethier, V. G. 1954. Evolution of feeding preferences in phytophagous insects. Evolution 8:33-54.

Duffy, J. E., and M. E. Hay. 1991. Food and shelter as determinants of food choice in an herbivorous marine amphipod. Ecology 72:1286-1298.

Duffy, J. E., and M. E. Hay. 1994. Herbivore resistance to seaweed chemical defense: the roles of mobility and predation risk. Ecology 75:1304-1319.

Duffy, J. E., and M. E. Hay. 2000. Strong impacts of grazing amphipods on the organization of a benthic community. Ecological Monographs 70:237-263.

Duffy, J. E., and V. J. Paul. 1992. Prey nutritional quality and the effectiveness of chemical defenses against tropical reef fishes. Oecologia 90:333-339.

Feeny, P. 1991. Chemical constraints on the evolution of swallowtail butterflies. Pages 315-340 in P. W. Price, T. M. Lewinsohn, G. W. Fernandes, and W. W. Benson, editors. Plantanimal interactions: evolutionary ecology in tropical and temperate regions. John Wiley and Sons, New York, New York, USA.

Foster, S. A. 1999. The geography of behavior: an evolutionary perspective. Trends in Ecology and Evolution 14:190-195.

Fox, C. W., J. K. Waddell, and T. A. Mousseau. 1994. Hostassociated fitness variation in a seed beetle (Coleoptera: Bruchidae): evidence for local adaptation to a poor quality host. Oecologia 99:329-336.

Fox, L. R., and P. A. Morrow. 1981. Specialization: species property or local phenomenon? Science 211:887-893.

Fritz, R. S., and E. L. Simms, editors. 1992. Plant resistance to herbivores and pathogens: ecology, evolution, and genetics. University of Chicago Press, Chicago, Illinois, USA.

Fry, J. D. 1990. Trade-offs in fitness on different hosts: evidence from a selection experiment with a phytophagous mite. American Naturalist 136:569-580.

Futuyma, D. J. 1991. Evolution of host specificity in herbivorous insects: genetic, ecological, and phylogenetic aspects. Pages 431-453 in P. W. Price, T. M. Lewinsohn, G. W. Fernandes, and W. W. Benson, editors. Plant-animal interactions: evolutionary ecology in tropical and temperate regions. John Wiley and Sons, New York, New York, USA.

Guarna, M. M., and R. L. Borowsky. 1993. Genetically controlled food preference: biochemical mechanisms. Proceedings of the National Academy of Sciences 90:5257-5261.

Hare, J. D., and G. G. Kennedy. 1986. Genetic variation in plant-insect associations: survival of Leptinotarsa decemlineata populations on Solanum carolinense. Evolution 40: 1031-1043.

Hay, M. E. 1992. The role of seaweed chemical defenses in the evolution of feeding specialization and in the mediation of complex interactions. Pages 93-118 in V. J. Paul, editor. Eco- logical roles of marine natural products. Comstock, Ithaca, New York, USA.

Hay, M. E. 1997. The ecology and evolution of seaweed-herbivore interactions on coral reefs. Coral Reefs 16:S67-S76.

Hay, M. E., J. E. Duffy, C. A. Pfister, and W. Fenical. 1987. Chemical defense against different marine herbivores: are amphipods insect equivalents? Ecology 68:1567-1580.

Hay, M. E., and W. Fenical. 1988. Marine plant-herbivore interactions: the ecology of chemical defense. Annual Review of Ecology and Systematics 19:111-145.

Hay, M. E., Q. E. Kappel, and W. Fenical. 1994. Synergisms in plant defenses against herbivores: interactions of chemistry, calcification and plant quality. Ecology 75:1714-1726.

Hay, M. E., and P. D. Steinberg. 1992. The chemical ecology of plant-herbivore interactions in marine versus terrestrial communities. Pages 372-414 in G. A. Rosenthal and M. R. Berenbaum, editors. Herbivores: their interactions with secondary plant metabolites. Second edition. Volume II: ecological and evolutionary processes. Academic Press, San Diego, California, USA.

Holmlund, M. B., C. H. Peterson, and M. E. Hay. 1990. Does algal morphology affect amphipod susceptibility to fish predation? Journal of Experimental Marine Biology and Ecology 139:65-83.

Janzen, D. H. 1980. When is it coevolution? Evolution 34:611612.

Jermy, T. 1984. Evolution of insect/host plant relationships. American Naturalist 124:609-630.

Lubchenco, J., and S. D. Gaines. 1981. A unified approach to marine plant-herbivore interactions. I. Populations and communities. Annual Review of Ecology and Systematics 12:405437.

Mangione, A. M., M. D. Dearing, and W. H. Karasov. 2000. Interpopulation differences in tolerance to creosote bush resin in desert woodrats (Neotoma lepida). Ecology 81:2067-2076.

Mauricio, R., and M. D. Rausher. 1997. Experimental manipulation of putative selective agents provides evidence for the role of natural enemies in the evolution of plant defense. Evolution 51:1435-1444.

Mitter, C., B. Farrell, and B. Wiegmann. 1988. The phylogenetic study of adaptive zones: has phytophagy promoted insect diversification? American Naturalist 132:107-128.

Nelson, W. G. 1980a. A comparative study of amphipods in seagrasses from Florida to Nova Scotia. Bulletin of Marine Science 30:80-89.

Nelson, W. G. 1980b. Reproductive patterns of gammaridean amphipods. Sarsia 65:61-71.

Padilla, D. K. 1985. Structural resistance of algae to herbivores. Marine Biology 90:103-109.

Pennings, S. C., M. T. Nadeau, and V. J. Paul. 1993. Selectivity and growth of the generalist herbivore Dolabella auricularia feeding upon complementary resources. Ecology 74:879-890.

Poore, A. G. B., and P. D. Steinberg. 2001. Host plant adaptation in a herbivorous marine amphipod: genetic potential not realized in field populations. Evolution 55:68-80.

Rausher, M. D. 1982. Population differentiation in Euphydryas editha butterflies: larval adaptation to different hosts. Evolution 36:581-590.

Rausher, M. D. 1984. Tradeoffs in performance on different hosts: evidence from within- and between-site variation in the beetle Deloyala guttata. Evolution 38:582-595.

Rausher, M. D. 1988. Is coevolution dead? Ecology 69:898901.

Rice, W. R. 1989. Analyzing tables of statistical tests. Evolution 43:223-225.

Richardson, J. P. 1979. Overwintering of Dictyota dichotoma (Phaeophyceae) near its northern distribution limit on the east coast of North America. Journal of Phycology 15:22-26.

Roa, R. 1992. Design and analysis of multiple-choice feedingpreference experiments. Oecologia 89:509-515. 
Rosenthal, G. A., and M. R. Berenbaum, editors. 1992. Herbivores: their interactions with secondary plant metabolites. Second edition. Volume II: ecological and evolutionary processes. Academic Press, San Diego, California, USA.

Schupp, P. J., and V. J. Paul. 1994. Calcium carbonate and secondary metabolites in tropical seaweeds: variable effects on herbivorous fish. Ecology 75:1172-1185.

Scriber, J. M. 1986. Origins of the regional feeding abilities in the tiger swallowtail butterfly: ecological monophagy and the Papilio glaucus australis subspecies in Florida. Oecologia 71: 94-103.

Simms, E. L., and M. D. Rausher. 1993. Patterns of selection on phytophage resistance in Ipomoea purpurea. Evolution 47: 970-976.

Slansky, F., Jr. 1992. Allelochemical-nutrient interactions in herbivore nutritional ecology. Pages 135-174 in G. A. Rosentha and M. R. Berenbaum, editors. Herbivores: their interactions with secondary plant metabolites. Second edition. Volume II ecological and evolutionary processes. Academic Press, San Diego, California, USA.

Sotka, E. E., M. E. Hay, and J. D. Thomas. 1999. Host-plant specialization by a non-herbivorous amphipod: advantages for the amphipod and costs for the seaweed. Oecologia 118:471482

Stachowicz, J. J., and M. E. Hay. 1999. Reducing predation through chemically mediated camouflage: indirect effects of plant defenses on herbivores. Ecology 80:495-509.

Stachowicz, J. J., and M. E. Hay. 2000. Geographic variation in camouflage specialization by a decorator crab. American Naturalist 156:59-71

Stanhope, M. J., B. Hartwick, and D. Baillie. 1993. Molecular phylogeographic evidence for multiple shifts in habitat preference in the diversification of an amphipod species. Molecular Ecology 2:99-112.

Steinberg, P. D., J. A. Estes, and F. C. Winter. 1995. Evolutionary consequences of food chain length in kelp forest communities. Proceedings of the National Academy of Sciences 92:81458148.

Steneck, R. S., and L. Watling. 1982. Feeding capabilities and limitation of herbivorous molluscs: a functional group approach. Marine Biology 68:299-319.

Strong, D. R., J. H. Lawton, and S. R. Southwood. 1984. Insects on plants: community patterns and mechanisms. Harvard University Press, Cambridge, Massachusetts, USA.

Sutherland, J. P., and R. H. Karlson. 1981. Development and stability of the fouling community at Beaufort, North Carolina. Ecological Monographs 47:425-446.

Sword, G. A., and E. B. Dopman. 1999. Developmental specialization and geographic structure of host plant use in a polyphagous grasshopper, Schistocerca emarginata (=lineata) (Orthoptera: Acrididae). Oecologia 120:437-445.

Thompson, J. N. 1993. Preference hierarchies and the origin of geographic specialization in host use in swallowtail butterflies. Evolution 47:1585-1595.

Thompson, J. N. 1994. The coevolutionary process. University of Chicago Press, Chicago, Illinois, USA.

Thompson, J. N. 1996. Tradeoffs in larval performance on normal and novel hosts. Entomologia Experimentalis et Applicata 80:133-139.

Travis, J. 1996. The significance of geographical variation in species interactions. American Naturalist 148:S1-S8.

Traxler, M. A., and A. Joern. 1999. Performance tradeoffs for two hosts within and between populations of the oligophagous grasshopper Hesperotettix viridis (Acrididae). Oikos 87:239_ 250 .

Trowbridge, C. D. 1991. Diet specialization limits herbivorous sea slug's capacity to switch among food species. Ecology 72: $1880-1888$.

Vermeij, G. J. 1987. Evolution and escalation: an ecological history of life. Princeton University Press, Princeton, New Jersey, USA.

Vermeij, G. J. 1992. Time of origin and biogeographical history of specialized relationships between northern marine plants and herbivorous molluscs. Evolution 46:657-664.

Via, S. 1984a. The quantitative genetics of polyphagy in an insect herbivore. I. Genotype-environment interaction in larval performance on different host plant species. Evolution 38: 881-895.

Via, S. 1984b. The quantitative genetics of polyphagy in an insect herbivore. II. Genetic correlations in larval performance within and among host plants. Evolution 38:896-905.

Via, S. 1990. Ecological genetics and host adaptation in herbivorous insects: the experimental study of evolution in natura and agricultural systems. Annual Review of Entomology 35: 421-446.

Williams, S. I., and D. I. Walker. 1999. Mesoherbivore-macroalgal interactions: feeding ecology of sacoglossan sea slugs (Mollusca, Opisthobranchia) and their effects on their fooc algae. Oceanography and Marine Biology: an Annual Review 37:87-128.

Zar, J. H. 1996. Biostatistical analysis. Third edition. PrenticeHall, Englewood Cliffs, New Jersey, USA 